\title{
16. EARLY EOCENE PALYNOFLORAS FROM HOLES 915A, 916A, 917A, AND 918D, EAST GREENLAND ${ }^{1}$
}

\author{
David W. Jolley²
}

\begin{abstract}
The dinoflagellate cysts, algae, pollen, and spores from the sediments immediately overlying the basalt seaward-dipping reflector sequences (SDRS) in Holes 915A, 916A, 917A, and 918D of Ocean Drilling Program Leg 152 were quantitatively recorded. Only the samples from Holes 916A and 918D yielded rich palynofloras, which in part proved to be correlative with each other. From the quantitative palynological data, a series of associations that represented sedimentation during at least three depositional sequences (parasequences?) was recognized and an age was attributed to the palynofloras using published dinoflagellate zonations. These results demonstrated that the normal polarity sediments recovered from the base of Hole 918D are attributable to Chron 23n, with the oldest sediments that rest on the SDRS being no older than $52 \mathrm{Ma}$. Analysis of archive material also suggested that sediments of this age are probably present on shore in East Greenland, as the Bopladsdalen Formation. Comparison with previously published accounts of the post-SDRS palynofloras in the Norwegian Sea suggests a similar age for the initiation of sedimentation in other areas of the region.

The rich terrestrial component of the pollen and spore flora is in accordance with the 51-52 Ma period of the Eocene temperature maximum; it contains several megatherm taxa and a high proportion of "paleotropical" forms. The dominant vegetation in the neighboring onshore areas during deposition of the immediately post-SDRS sediments appears to have been a notophylous evergreen forest. However, one period of short-term land-surface temperature fall is evident within the interval, with mean annual temperatures possibly cooling by up to $2^{\circ} \mathrm{C}$ for a period of less than $0.25 \mathrm{~m}$.y. During this period vegetation appears to have changed to a mixed mesophytic angiosperm swamp forest.
\end{abstract}

\section{INTRODUCTION}

The principal aim of the examination of the palynofloras present in the lowermost sediments of the boreholes drilled during Ocean Drilling Program (ODP) Leg 152 was to identify the age and depositional environment of the sediments overlying the seaward-dipping reflector sequences (SDRS) on the east coast of Greenland. It was anticipated that a significant thickness of sediments would be recovered from the older part of the lower Eocene approximating to calcareous nannofossil Zones NP9-NP12. This would have allowed a northward extension of the detailed palyno- and magnetostratigraphy undertaken by Jolley $(1992,1996)$ and Ali and Jolley (1996) in southeastern England. However, the amount of sediment of this age recovered was small, in contrast to Leg 104 to the northeast, where Boulter and Manum (1989) recorded extensive sequences of this age. The paucity of recovery of such sediments in the leg necessitated focusing of this palynological study on the age dating and correlation of the basal units in four of the boreholes.

Weighed subsamples of the material provided by ODP were subjected to palynological processing, involving hydrofluoric acid for digestion of silicates and oxidation using dilute nitric acid. At all stages during preparation, the residue was sieved through a $7-\mu \mathrm{m}$ sieve: the resultant strew mounts being examined using a phase contrast optical microscope. The results of the analysis are given below. The taxonomic nomenclature of the dinoflagellate cysts follows that of Lentin and Williams (1993); that of the pollen and spore taxa is given in the Appendix.

Saunders, A.D., Larsen, H.C., and Wise, S.W., Jr. (Eds.), 1998. Proc. ODP, Sci. Results, 152: College Station, TX (Ocean Drilling Program).

${ }^{2}$ Centre for Palynological Studies, University of Sheffield, Mappin Street, Sheffield S1 3JD, United Kingdom. d.w.jolley@ sheffield.ac.uk

\section{PALYNOFLORAS}

\section{Hole 915A}

Two Hole 915A samples were examined from the conglomeratic volcanic silty sediments beneath the silts and sandy silts containing nannofossils diagnostic of Zone CP14a. Although large quantities of black woody debris (inertinite) were present, no structured organic fossils were observed, leaving the age of the basal sediments at this site in question. Observations on samples taken from Hebridean bole horizons (Jolley, in press), would suggest that this type of palynofacies is in accordance with the alluvial fan environment proposed for this lithologic unit (Unit III).

\section{Hole 916A}

A further cored section of lithologic Unit III, a volcanic breccia, was sampled in Hole 916A, along with silts and volcanic silts and clays of lithologic Unit II. The palynofloras recovered from this interval were of a wholly terrestrial origin, being dominated by Inaperturopollenites hiatus and Alnipollenites verus, Caryapollenites circulus, C. veripites, Laevigatosporites haardtii, Pityosporites spp., and Microthallites spp. Together with the total lack of any microplankton, this palynoflora suggests a lacustrine, or sheltered lagoonal environment of deposition. The palynofloras appear to have been derived from a dominant Taxodiaceae-Betulaceae swamp (Collinson, 1992), a Juglandaceae-dominated angiosperm swamp forest, and an angiosperm flood plain community together with transported elements from a montane conifer forest. This mixture of floral communities is suggestive of transported assemblages with a dominance of lowland swamp vegetation, typical of fluvio-deltaic environments in the late Paleocene to early Eocene.

\section{Hole 917A}

The sands and volcanic conglomerates sampled from lithologic Unit III and igneous Unit 33 yielded impoverished palynofloras. Iso- 


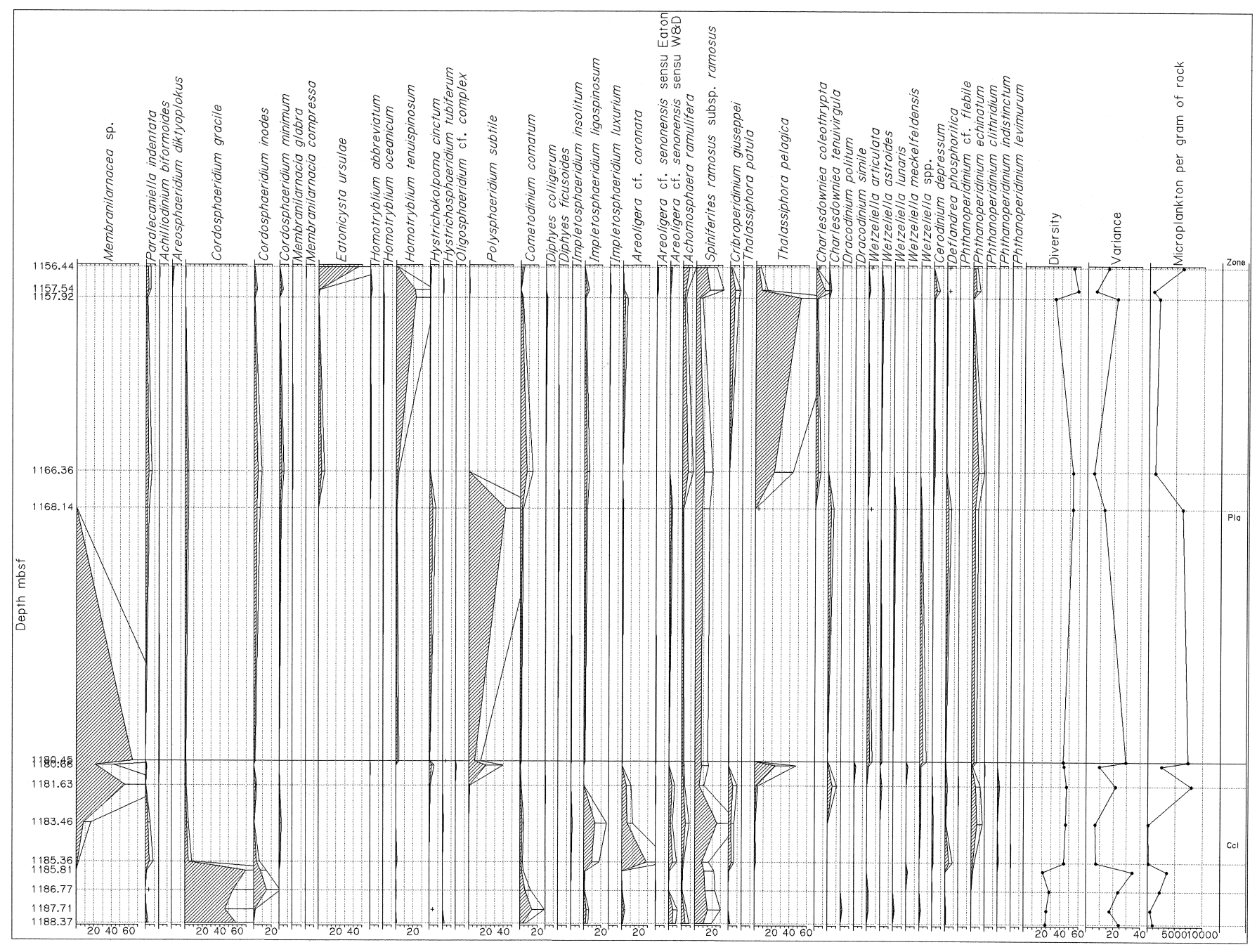

Figure 1. Normalized selective frequency plot of microplankton taxa recorded in Hole 918D. The variance plot on the right demonstrates the changes in relative sea level discussed in the text. The solid horizontal line denotes a zonal boundary; the dotted lines represent the boundaries between associations.

lated specimens of the dinoflagellate cysts Operculodinium centrocarpum and Spiniferites ramosus subsp. ramosus occur at $183.54 \mathrm{~m}$ (all depths in this paper are given as meters below seafloor [mbsf]) and single specimens of Inaperturopollenites hiatus and Laevigatosporites haardtii occur at $195.18 \mathrm{~m}$, but these provide no significant age-dating information. Similarly, small offcut samples provided by J. Ali from the pre-basaltic metasediments of lithologic Unit IV proved to be barren of palynomorphs.

\section{Hole 918D}

The most extensive group of samples studied came from Hole 918D in the lower Eocene section between $1156.44 \mathrm{~m}$ and 1188.37 $\mathrm{m}$. These 14 samples yielded a rich and abundant palynoflora, with both marine and terrestrial components being well represented. The marine microplankton flora recovered from the glauconitic, black volcaniclastic silts of lithologic Unit V (Larsen, Saunders, and Clift, et al., 1994) which rest unconformably on the weathered basalts of the SDRS, contain a marine microplankton palynoflora dominated by taxa typical of the early Eocene. The dinoflagellate cysts Cordosphaeridium gracile, Eatonicysta ursulae, Homotryblium tenuispinosum, Polysphaeridium subtile, Spiniferites ramosus subsp. ramosus, and Thalassiphora pelagica all occur abundantly. Similarly, the pollen flora is dominated by Inaperturopollenites hiatus, Caryapollenites veripites, Nyssapollenites kruschii subsp. analepticus, and
Pityosporites spp. The richness and diversity of the record is suggestive of deposition in a marine shallow shelf environment, concordant with the presence of common glauconite in the sediment.

\section{STRATIGRAPHY}

\section{Age of the Palynofloras}

Hole $918 \mathrm{D}$ is of primary importance in assessing the indications of age suggested by the palynofloras, as it represents the most complete section available. The palynofloras of 918D can be subdivided into eight palynological associations (sensu Jolley, 1992); these associations are briefly described below, oldest to youngest, and in Figures 1 and 2.

The lowermost samples recovered from the ashy glauconitic sandy silts contain two associations, a Cordosphaeridium gracileCometodinium comatum association and a Cordosphaeridium gracile-C. inodes association with common Areoligera cf. senonensis and common Spiniferites ramosus subsp. ramosus also present. In the immediately overlying sediments, the palynoflora changes completely to an Impletosphaeridium ligospinosum-Areoligera $\mathrm{cf}$. coronata association, which also contains common Cribroperidinium giuseppei and Phthanoperidinium echinatum. This association is succeeded by a Membranilarnacea sp.-Thalassiphora pelagica association, which contains common Polysphaeridium subtile and Charlesdowniea co- 


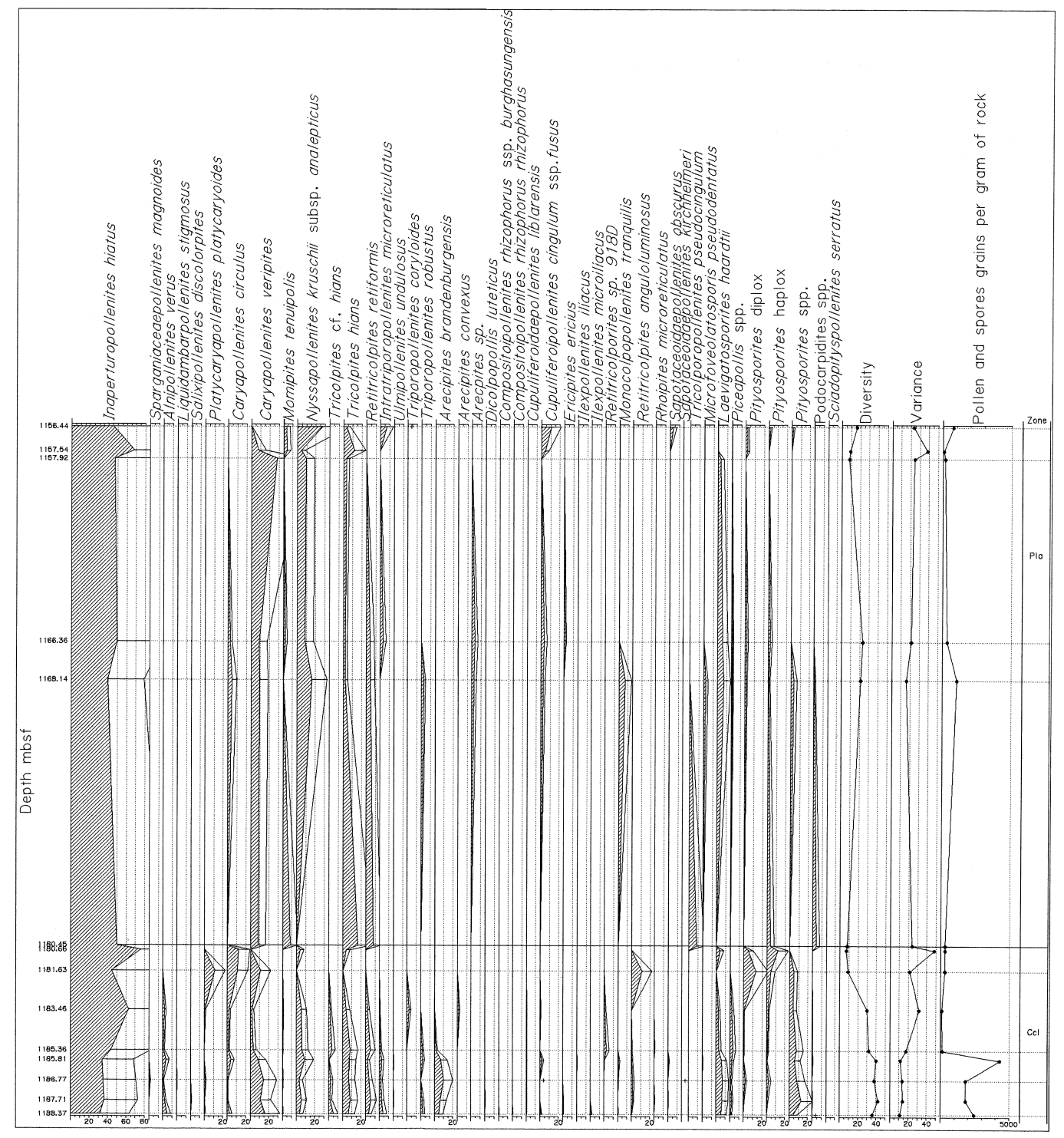

Figure 2. Normalized selective frequency plot of pollen and spore taxa recorded in Hole 918D. The variance plot on the right demonstrates the proximity of the hole to the terrestrial source. The solid horizontal line denotes a zonal boundary; the dotted lines represent the boundaries between associations.

leothrypta. Immediately above the basalt sill, a Polysphaeridium subtile-Hystrichokolpoma cinctum association precedes a series of associations dominated by $T$. pelagica and later Homotryblium tenuispinosum. The uppermost sample is characterized by a switch to an Eatonicysta ursulae-Areosphaeridium diktyoplokus association in the nannofossil chalks and clays at the base of lithologic Unit IV.

Although a series of nearby studies of Eocene dinoflagellate cyst palynofloras has been undertaken and zonations proposed (Manum et al., 1989; Costa and Downie, 1979), the highest resolution zonation available for the region is that proposed by Powell (1992). Although this is a zonation based primarily on material from around the North Sea Basin, similarity with offshore East Greenland means that it can be applied with success. Similarly, the zonation of Bujak and Mudge (1994) for the North Sea Basin provides valuable information of the first downhole occurrences of taxa, some of which were not considered by the earlier Powell (1992) zonation.

Both the Cordosphaeridium gracile-Cometodinium comatum and C. gracile-C. inodes associations (1185.31-1188.37 m) can be attributed to the lowermost part of Powell's (1992) Ccl Zone, which from the correlations presented by that author, is equivalent to the lower part of NP12 (lowermost CP10 of Okada and Bukry, 1980). The first occurrence of Phthanoperidinium echinatum at $1185.81 \mathrm{~m}$ is indicative of an intrabasal Zone Ccl age, as is the first appearance of Impletosphaeridium insolitum in the overlying Impletosphaeridium ligospinosum-Areoligera cf. coronata association at $1185.36 \mathrm{~m}$.

The last occurrence upsection of Dracodinium simile in the Membranilarnacea sp.-Thalassiphora pelagica association at $1180.45 \mathrm{~m}$ was shown by Bujak and Mudge (1994) to occur at the top of their E2b Zone, which they equated with the middle of Zone NP12 (CP10). Above the intruded sill, the information provided by the dinoflagellate cysts is less clear, with Diphyes ficusoides occurring in sediments that appear to be older than the intra Zone Pco suggested by Powell (1992). However, the first occurrence of Areosphaeridium diktyoplokus at $1156.44 \mathrm{~m}$ is indicative of an intra Zone Pla age (Powell, 1992), equivalent to the NP12/NP13 boundary (CP10/CP11).

\section{Comparison with the Magnetostratigraphy}

The shipboard magnetostratigraphic results from Hole 918D have been confirmed by Ali and Vandamme (this volume), and show that the sediments below $1185.00 \mathrm{~m}$ to the top of the basalts are of reversed polarity. Between $1185.00 \mathrm{~m}$ and the uppermost sample ex- 


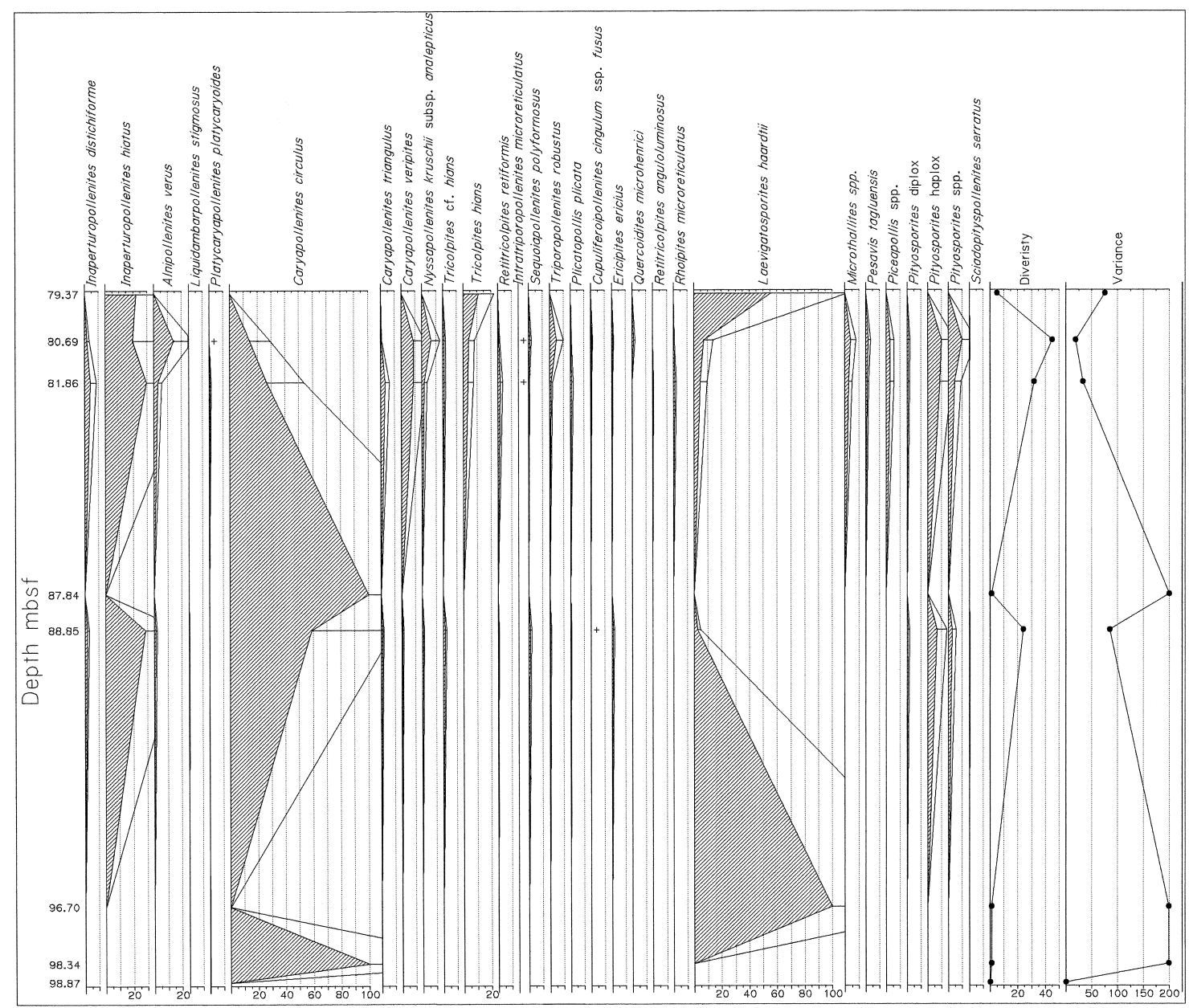

Figure 3. Normalized selective frequency plot for the palynoflora in the basal units of Hole 916A.

amined at $1156.44 \mathrm{~m}$, normal polarities are recorded, except in the intruded basaltic sill. This normal polarity interval was originally interpreted as being of C24n (Larsen, Saunders, Clift, et al., 1994), although biostratigraphical evidence for the age was lacking. However, as the sequence of dinoflagellate cyst zones shows, the reversed polarity interval at the base of the post-SDRS sediments must be attributable to $\mathrm{C} 23 \mathrm{r}$, with the overlying normal polarity interval to C23n.

The palynofloras of the section examined in Hole 916A are wholly of terrestrial origin, being composed of an Inaperturopollenites hiatus-Caryapollenites circulus association between 79.37 and 88.85 $\mathrm{m}$. No reliable zonations exist for terrestrial palynofloras in this region, those of Krutzsch (1966) relying on the presence of rare taxa and that of Schroder (1992) being applicable to the earliest Ypresian and Thanetian only. However, quantitative pollen data from southeastern England and the North Sea are available (Jolley, 1996). This suggests that the assemblages recovered are of Ypresian character of the kind seen in the lower part of the London Clay Formation, which contains high proportions of Caryapollenites spp. and Inaperturopollenites hiatus (Fig. 3).

However, it was found that the best method of age dating the terrestrial palynofloras of Hole $916 \mathrm{~A}$ was by a direct comparison with the terrestrial palynofloras in the Hole 918D data. Examination of the pollen and spore profiles in Hole 918D shows that an interval dominated by highly abundant $I$. hiatus, with common occurrences of Caryapollenites spp., Retitricolpites retiformis, Tricolpites hians and $T$. cf. hians occurs in the lower part of the interval studied at 1185.36-
$1180.45 \mathrm{~m}$. Both above and below this interval, frequencies of thermophyllic taxa (e.g., Arecipites species and Sapotaceoidaepollenites species) increase in a terrestrial palynoflora of greater diversity. This correlation indicates that the terrestrial palynofloras of Hole 916A are equivalent to Zone Ccl of Powell (1992) and to nannofossil Zones NP12 or CP10 (Fig. 4).

The magnetostratigraphical analysis of Hole 916D shows that the entire interval of study is recorded as an unattributed normal polarity event. The palynology clearly demonstrates that this normal is the lowermost part of C23n, also seen in Hole 918D.

\section{Comparison with Published Literature}

Sections studied from intrabasaltic sediments in eastern Greenland have been detailed by Soper and Costa (1976), Soper et al. (1976a), and Soper et al. (1976b). Fortunately, it has proved possible during 1988 to examine the slides of Soper and Costa (1976) held in the reference collection of the Centre for Palynological Studies, University of Sheffield. Samples GGU179232 and 116342, both from the upper dike-free part of the Kap Dalton Group, yielded abundant pollen and spores, although only 179232 yielded dinoflagellate cysts.

The dinoflagellate cysts recorded were dominated by Apectodinum species, including A. parvum, A. quinquelatum, and A. homomorphum. However, the occurrence of Wetzeliella meckelfeldensis reported by Soper and Costa (1976) was not recorded in the re-examination of the archive material. The terrestrial palynoflora of both samples was dominated by Inaperturopollenites hiatus, Pityosporites 


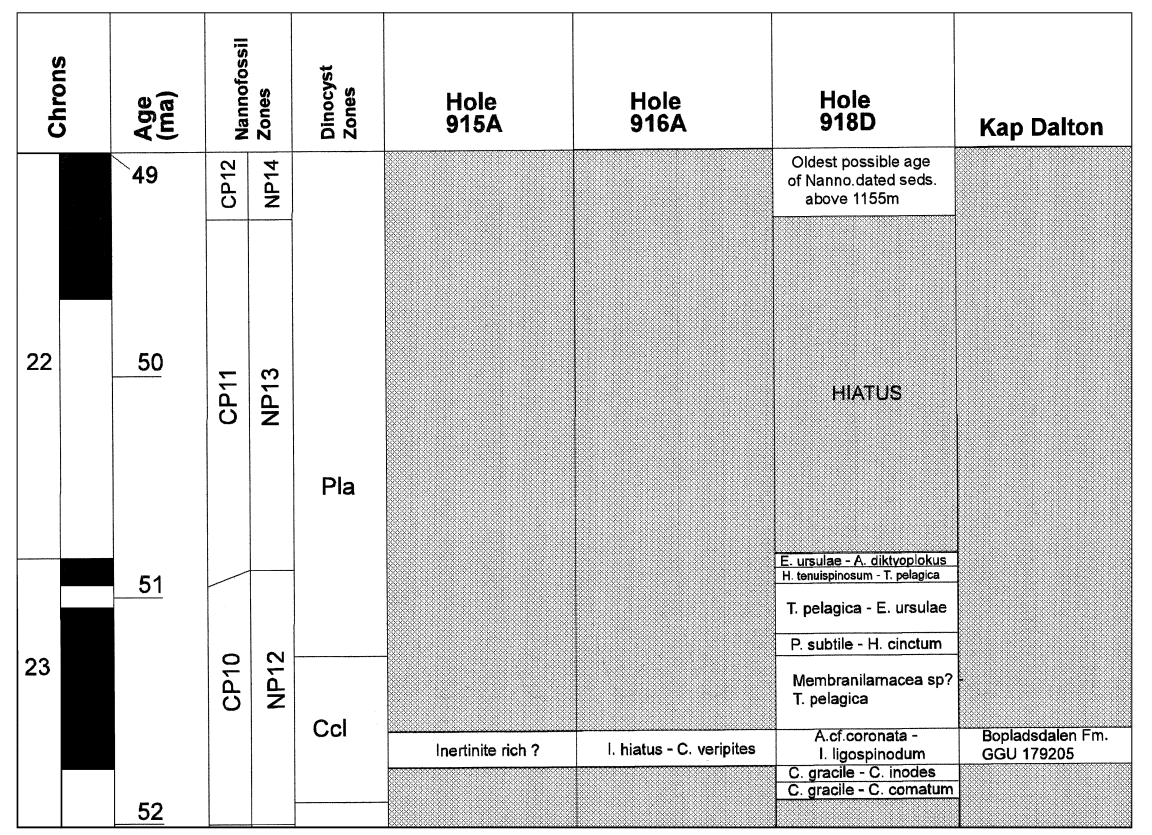

Figure 4. Comparison of the palynological age dating of the sediments in Holes 916A and 918D with the nannofossil zones of Okada and Bukry (1980) and Martini (1971), the magnetochrons, and potentially correlative sections in Hole 915A and at Kap Dalton.

spp., and abundant Intratriporopollenites microreticulatus; an assemblages present in the coeval North Sea Balder Formation and its lateral equivalents in the west of Shetland Islands area (Hitchen et al., 1995). The occurrence of Apectodinium species might be taken to indicate a comparison with the latest Paleocene interval recorded by Boulter and Manum (1989) in Hole 642E. However, the lack of Apectodinium augustum in the Kap Dalton material does not support this comparison, neither does the pollen flora, that of Hole 642E containing common Caryapollenites spp. and occurrences of Aquilapollenites spinulosus.

Re-examination of the palynofloras in samples 179205 from the Bopladsdalen Formation and 179208 from the Krabbedalen Formation was also undertaken. Although the taxa recorded from sample 17205 by Soper and Costa (1976) were not recognized in the archive material, common occurrences of Caligodinium amiculum, Leiosphaera spp., and Pterospermella spp. were present together with a rich pollen palynoflora, indicating a nearshore environment of lower than normal salinity. This assemblage included abundant Pityosporites spp., Alnipollenites verus, Caryapollenites circulus, and Inaperturopollenites hiatus; it is similar to that recorded in Hole 916A. This suggests that the East Greenland sample is correlative with those recorded in the Irminger Basin, and is equivalent to dinoflagellate cyst Zone $\mathrm{Ccl}$, giving an age of around 52.5 Ma for these sediments (Fig. 4). The examination of archive material from sample 179208 yielded assemblages dominated by Phthanoperidinium clithridium with Areosphaeridium diktyoplokus and a pollen assemblage containing Lymingtonia rhaetor, a palynoflora characteristic of the midmiddle Eocene.

The Outer Vøring plateau ODP borehole 643A studied by Manum et al. (1989) and Boulter and Manum (1989) yielded Eocene palynofloras, which are rich in dinoflagellate cysts. However, the majority of the section studied by these authors is younger than the material in consideration here. A limited number of samples from the early Eocene were studied. The first occurrence of Areosphaeridium diktyoplokus at $541.90 \mathrm{~m}$, marking the presence of palynofloras equated to Zone Pla, approximates to the NP12/NP13 boundary. The palynoflora of the lowermost sample in this hole at $556.71 \mathrm{~m}$ contains common
Eatonicysta ursulae and is probably also referable to Zone Ccl, although they were attributed to different biozones by Manum et al. (1989). No correlative terrestrial palynofloras are recognizable in the data presented by Manum et al. (1989). The presence of Azolla massulae at the base of the Hole 643A section implies local freshwater input, but the pollen flora is otherwise apparently dominated by bisaccates.

Similarly, the presence/absence data provided by Manum et al. (1989) for Hole 642E show the presence of Phthanoperidinium echinatum in an assemblage including Eatonicysta ursulae, Cerebrocysta bartonensis, Samlandia chlamydophora, and Achilliodinium biformoides. Manum et al. (1989) assigned and age older than that attributed to the basal sediments present in Hole 643A to this assemblage. However, the presence of $C$. bartonensis suggests that an assignment to Zone Pla, equivalent to nannofossil Zone NP13, is preferable.

In an earlier work, Manum (1976) studied a series of palynological assemblages from ODP boreholes on the Vøring Plateau, with lower Eocene sediments being recovered from Hole 338. Unfortunately, the presence/absence data presented by Manum makes any reliable comparison to the current study impractical, although the occurrences of Deflandrea phosphoritica and Thalassiphora pelagica in his Zone VIIa suggest that a correlation with the Zone Ccl palynofloras of Hole 918D is possible.

The data presented from Goban Spur ODP Hole 548A by Brown and Downie (1984) are more limited than that of Manum et al. (1989), with only a few presence-absence records for the NP11NP12 interval at the base of the Eocene section. Here, the presence of Dracodinium condylos, a taxon restricted to Zone Ccl, suggests that the base of the Eocene is of a similar age in this area.

\section{PALEOENVIRONMENTS}

\section{Evidence for Sea Level Change}

The identification of relative sea level changes from palynological data is greatly aided by the analysis of variance within the studied samples. Together with the composition of the microplankton assem- 
blages, these data suggest that the dominance of Cordosphaeridium species in the lowermost interval of Zone Ccl (1188.37-1185.81 m), together with common Spiniferites ramosus subsp. ramosus, Cometodinium comatum, and the low frequencies of peridinioid cysts, is suggestive of middle to outer neritic assemblages. This initial depositional phase onlapping the SDRS is succeeded by assemblages in which Areoligera cf. coronata is an important component along with Impletosphaeridium ligospinosum. Islam (1984) and Brinkhuis (1994) regarded the presence of common specimens of Areoligera spp. as indicative of turbid, perhaps lowered salinity, transgressive environments. The composition of the remainder of these assemblages supports a neritic environment, although the increased frequencies of Phthanoperidinium spp. may be indicative of deeper water conditions. The implication of the presence of common Areoligera cf. coronata is that these assemblages were deposited during a turbid water transgressive phase, an interpretation supported by the microplankton variance data (Fig. 1). Whereas the increasing microplankton variance in the Cordospharidium-dominated associations is indicative of a relative sea level fall, the abrupt upward shift in variance at the onset of the Areoligera-dominated association marks the base of a strongly transgressive phase, perhaps reflecting a sequence boundary. This is supported by the pollen and spore data, which show falling diversities and increasing variance across this boundary.

Above the Areoligera-dominated association, the Membranilarnacea sp.-Thalassiphora pelagica association represents deposition during a period of apparently fluctuating relative sea levels. The change from Membranilarnacea sp. and Polysphaeridium subtile dominance to $T$. pelagica dominance is mirrored in the variance trend suggesting an overall shallowing with a short-lived, more distal phase in between. The presence of $P$. subtile is indicative of restricted circulation water. The existence of such a high environmental stress (?low salinity) water mass could explain the dominance of the unusual form of Membranilarnacea sp.

Above the intervening sill, the dominance of Polysphaeridium subtile becomes complete, suggesting shallow neritic conditions and, in comparison to extant $P$. zoharii, confirming the tropical nature of the water mass (Harland, 1984). Succeeding associations show a dominance by Thalassiphora pelagica, Spiniferites ramosus subsp. ramosus, Achomosphaera ramulifera, and Cometodinium comatum. These associations suggest the establishment of more open marine neritic conditions, which are soon succeeded by T. pelagica- and Homotryblium tenuispinosum-dominated associations indicating high stress shelf conditions, perhaps with higher salinities (Brinkhuis, 1994). At the upper limit of the analyzed interval, the influx of $E a$ tonicysta ursulae and Spiniferites ramosus subsp. ramosus, indicates resumption of more normal marine circulation conditions. This is confirmed by the first appearance of Areosphaeridium diktyoplokus (Brinkhuis, 1994) and a decline in peridinioid cysts.

\section{Paleoclimate}

Although the general composition of the microplankton palynoflora implies the continued existence of warm, tropical waters throughout most of the interval, the current knowledge of the environmental preferences of fossil dinoflagellate cyst taxa is insufficient to allow more than general comments. However, the quality of the pollen spectra obtained from Holes 916A, 918D, and onshore Greenland enables comment on land surface temperature and the nature of the source vegetation.

Two approaches have been taken to estimate land surface temperature and the composition of the regional vegetation. The presence of megatherm taxa within the section was used to indicate periods of maximum mean annual temperature (MAT) for the interval. In addition, the quantitative composition of the whole palynoflora was used to allow analysis of the paleocommunities present. This was achieved by comparison to a database of pollen and spore ecological groupings generated using detrended correspondence analysis of over 150 sam- ples and 300 taxa from the northwest European Paleocene and Eocene (Jolley, unpubl. data). This approach was first adopted by Boulter and Hubbard (1982), who used principal components analysis to generate forest groupings that were compared to modern forest types defined by Wolfe (1979). Unfortunately, the taxonomic approach of Boulter and Hubbard was not compatible with that used here, necessitating the preparation of a new data set. Marine environments contain a jumble of palynofloras derived from several different forest types; the frequency and composition of these assemblages can be interpreted to create analogies to modern forests, and to infer MAT in the manner adopted by Boulter and Hubbard (1982).

The pollen record obtained from Hole $918 \mathrm{D}$ is of good quality and high diversity. High frequencies of Inaperturopollenites hiatus imply the continued presence of a littoral Taxodium swamp community. Between $1188.37 \mathrm{~m}$ and $1185.36 \mathrm{~m}$, the terrestrial palynoflora is dominated by a notophylous angiosperm forest, with a high proportion of megatherm taxa including Arecipites spp. and Sapotaceoidaepollenites spp. Using the average mean annual temperature figures for the corresponding forest types proposed by Boulter and Hubbard (1982), maximum MAT estimates of between $15^{\circ}$ and $17^{\circ} \mathrm{C}$ are suggested for this forest. In addition to the lowland terrestrial palynoflora, large numbers of bisaccate pollen transported from a montane conifer forest are present. The occurrence of Aquilapollenites spinulosus in this interval may be regarded as reworking, the occurrence of this taxon having been recorded in the Upper Cretaceous to lowermost Tertiary of Greenland by Croxton (1980). Occurrences of this taxon in Paleogene sediments are known elsewhere, particularly in the earliest Ypresian of the west of Shetland Islands and inner Hebrides areas, where the taxon occurs at the base of a depositional sequence in terrestrial sediments. Jolley (in press) remarked on the possibility that this taxon, probably a member of the Santalaceae (Jarzen, 1977), may have survived as an epiphyte in primary colonizing communities within the Ypresian. The record of the taxon in the pollen floras at the base of Hole 918D is analogous to these records, suggesting that the parent plant formed part of a primary colonizing flora on the basalt surface.

The interval between $1183.46 \mathrm{~m}$ and $1180.45 \mathrm{~m}$ contains a significantly different pollen and spore flora to that immediately underlying it. It is best represented by the section in Hole 916A between $98.87 \mathrm{~m}$ and $79.37 \mathrm{~m}$, which is a time equivalent unit in a more proximal setting. Inaperturopollenites hiatus and I. distichiforme dominate the flora, being derived from a littoral Taxodium swamp, which shows evidence for a rising water table in the upper part of the interval as it incorporates significant frequencies of pollen produced by trees of the Betulaceae (Alnipollenites verus) and Nyssaceae (Nyssapollenites spp.). Both Caryapollenites veripites and C. circulus occur in abundance, all these taxa being derived from a Juglandaceous dominated angiosperm swamp forest. A significant part of this forest was composed of the parent plants producing the common specimens of Retitricolpites retiformis and Tricolpites hians. These appear to have been derived from a flood plain angiosperm community in other records of the northwest European Paleogene (Jolley, in press). There is no contribution from warmer forest types or megatherm taxa, supporting the interpretation of climatic cooling, which is reinforced by the MAT figures generated by the average method proposed by Boulter and Hubbard (1982), which suggests maximum MAT temperatures of around $14^{\circ} \mathrm{C}$.

In the remainder of the studied section in Hole 918D, the pollen flora, although deposited in an increasingly distal marine setting, is of essentially the same character as that encountered in the lowermost interval, suggesting a return of warmer forest types. Certain taxa present in this and the lowermost interval are indicative of a subtropical climate. In particular, the occurrences of Arecipites spp., Dicolpopollis luteticus, and Sapotaceoidaepollenites spp. are characteristic of megathermal taxa seen during the Eocene temperature maximum at high latitudes, (Wolfe, 1981, 1990). Wing and Greenwood (1994) used the presence of palm pollen (Arecipites spp., Dicolpopol- 


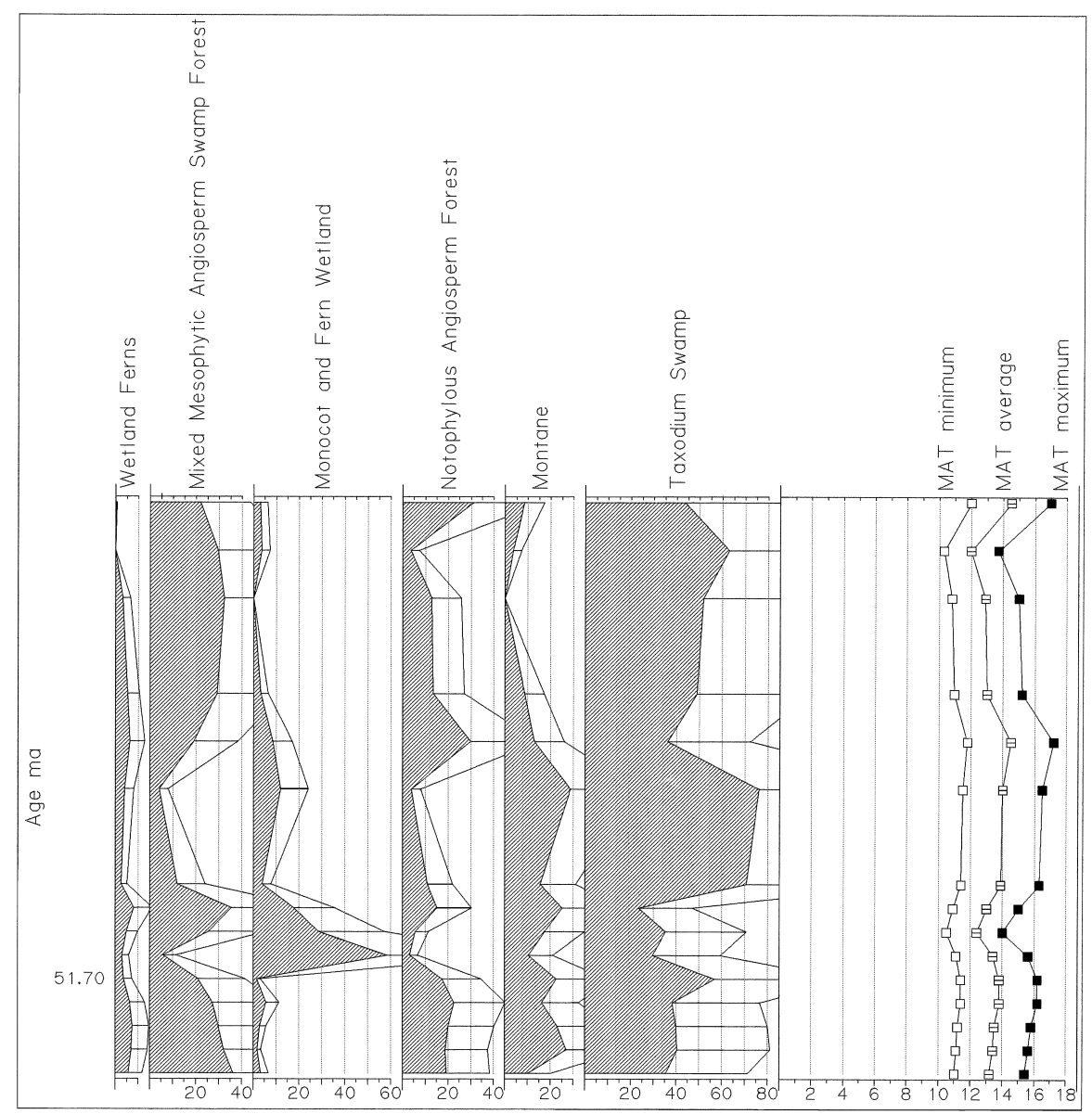

Figure 5. Normalized distribution of the major forest types represented by the pollen and spore record in the sampled sections. The graph on the right shows the estimates of mean annual temperature (MAT) in degrees Celsius derived using the methodology of Boulter and Hubbard (1982). In addition, maximum and minimum figures for the MAT are given taking maximum and minimum temperature parameters for the analogous modern forest types used by Boulter and Hubbard, which were derived from Wolfe (1979).

lis spp.) to indicate subtropical climates in the interior of the United States during the Eocene temperature maximum. The occurrence of these taxa in the Hole 918D material (intervals 1188.37-1185.36 m and 1168.14-1156.44 $\mathrm{m}$ ) confirms the existence of low altitude notophylous angiosperm forests at high latitudes during this period. This forest may have given way to mixed mesophytic forests inland, passing with increasing altitude into montane conifer forest. However, the composition of the palynoflora in the interval of 1183.46-1180.45 m in Hole 918D, the whole of the section studied in Hole 916A and in the Bopladsdalen Formation samples of Soper and Costa (1976) from Kap Dalton, suggests the presence of a short-term change in the floral composition. These assemblages are derived from a mixed mesophytic angiosperm swamp forest. This is confirmed by the MAT calculations derived from the average MATs of modern analogs (Fig. 5). This suggests that a short-term cooling took place at around $51.7 \mathrm{Ma}$ with MATs dropping by about $2^{\circ} \mathrm{C}$, before surpassing the levels prior to $51.70 \mathrm{Ma}$.

The causal factor behind this fall in MAT remains enigmatic, primarily due to the small size of the database available for this region. The rifting of this part of the North Atlantic and its consequent effect on oceanic circulation does not appear to have been an initial contributor to the Eocene temperature maximum, MATs having been rising since around 53.75 Ma in southern England (Jolley, in press), although the major increment in MAT appears to have come at around $52.5 \mathrm{Ma}$. The dating of the basal sediments resting on the SDRS at about 52-51.7 Ma indicates that they lie within the period of the tem- perature maximum (Wing and Greenwood, 1994) of 51-52 Ma. Indeed, the composition of the palynoflora in the basal units of Hole 918D suggests that the flora colonizing the surface of the SDRS already included megatherm taxa among its components.

\section{ACKNOWLEDGMENTS}

The author would like to thank Dr. Jason Ali for his enthusiastic collaboration in the early stages of this project and Dr. E. Spinner and Dr. Sarah Wilson for their constructive comments on the manuscript.

\section{REFERENCES}

Ali, J.R., and Jolley, D.W., 1996. Biostratigraphically constrained magnetostratigraphy of the Late Paleocene and Early Eocene of the Anglo-Belgium-Paris Basin. In Knox, R.W.O'B., Corfield, R., and Dunay, R.E. (Eds.), Correlation of the Early Paleogene in Northwest Europe. Geol. Soc. Spec. Publ. London, 101:129-144.

Boulter, M.C., and Hubbard, R.N.L.B., 1982. Objective paleoecological and biostratigraphic interpretation of Tertiary palynological data by multivariate statistical analysis. Palynology, 6:55-68.

Boulter, M.C., and Manum, S.B., 1989. The Brito-Arctic igneous province flora around the Paleocene/Eocene boundary. In Eldholm, O., Thiede, J., Taylor, E., et al., Proc. ODP, Sci. Results, 104: College Station, TX (Ocean Drilling Program), 663-680.

Brinkhuis, H., 1994. Late Eocene to early Oligocene dinoflagellate cysts from the Priabonian type-area (Northeast Italy): biostratigraphy and pale- 
oenvironmental interpretation. Palaeogeogr., Palaeoclimatol., Palaeoecol., 107:121-163.

Brown, S., and Downie, C., 1984. Dinoflagellate cyst biostratigraphy of late Paleocene and early Eocene sediments from Holes 552, 553A, and 555, Leg 81, Deep Sea Drilling Project (Rockall Plateau). In Roberts, D.G., Schnitker, D., et al., Init. Repts. DSDP, 81: Washington (U.S. Govt. Printing Office), 565-579.

Bujak, J.P., and Mudge, D.C., 1994. A high resolution North Sea Eocene dinocyst zonation. J. Geol. Soc. London, 151:449-462.

Collinson, M.E., 1992. Vegetational and floristic changes around the Eocene/ Oligocene boundary in western and central Europe. In Prothero, D.R., and Berggren, W.A. (Eds.), Eocene-Oligocene Climatic and Biotic Evolution: Princeton, NJ (Princetown Univ. Press), 437-450.

Costa, L., and Downie, C., 1979. Cenozoic dynocyst stratigraphy of Sites 403 to 406 (Rockall Plateau), IPOD, Leg 48. In Montadert, L., Roberts, D.G., et al., Init. Repts. DSDP, 48: Washington (U.S. Govt. Printing Office), 513-529.

Croxton, C.A., 1980. Aquilapollenites from the Late Cretaceous-Paleocene (?) of central West Greenland. Rapp.-Groenl. Geol. Unders., 101:5-27.

Harland, R., 1984. Distribution maps of Recent dinoflagellate cysts in bottom sediments from the North Atlantic Ocean and adjacent seas. Palaeontology, 26:321-387.

Hitchen, K., Jolley, D.W., Harland, R., and Jones, J.M., 1995. Regional implications of micropalaeontological and palaeo-environmental investigations of the early Eocene interval in BGS borehole 90/3, offshore NW Scotland. Scott. J. Geol., 31:117-124.

Islam, M.A., 1984. A study of early Eocene palaeoenvironments in the Isle of Sheppey as determined from microplankton assemblage composition. Tertiary Res., 6:11-21.0

Jarzen, D.M., 1977. Aquilapollenites and some Santalalean Genera, a botanical comparison. Grana, 16:29-39.

Jolley, D.W., 1992. Palynofloral association sequence stratigraphy of the Paleocene Thanet Beds and equivalent sediments in eastern England. Rev. Palaeobot. Palynol., 74:207-237.

1996.The earliest Eocene sediments of eastern England; an ultra high resolution palynological correlation. In Knox, R.W.O'B., Corfield, R., and Dunay, R.E. (Eds.), Correlation of the Early Paleogene in Northwest Europe. Geol. Soc. London Spec. Publ.,101:219-254.

- , in press. Palaeosurface palynofloras of the Skye lava field, and the age of the British Tertiary Volcanic Province. In Widdowson, M. (Ed.), Palaeosurfaces: Recognition, Reconstruction and Interpretation. Geol. Soc. London Spec. Publ.

Krutzsch, W., 1966. Die Sporenstratigraphische des alteren Tertiar im nordlichen Grundlagen und gegenwartiger Stand der untersuchungen. Abh. Zentr. Geol. Inst., 8:112-149.

Larsen, H.C., Saunders, A.D., Clift, P.D., et al., 1994. Proc. ODP, Init. Repts., 152: College Station, TX (Ocean Drilling Program).

Lentin, J.K., and Williams, G.L., 1993. Fossil dinoflagellates: index to genera and species, 1993 edition. Am. Assoc. Stratigr. Palynol. Contrib., 28:1856

Manum, S.B., 1976. Dinocysts in Tertiary Norwegian-Greenland Sea sediments (Deep Sea Drilling Project Leg 38), with observations on palynomorphs and palynodebris in relation to environment. In Talwani, M., Udintsev, G., et al., Init. Repts. DSDP, 38: Washington (U.S. Govt. Printing Office), 897-919.

Manum, S.B., Boulter, M.C., Gunnarsdottir, H., Rangnes, K., and Scholze, A., 1989. Eocene to Miocene palynology of the Norwegian Sea (ODP Leg 104). In Eldholm, O., Thiede, J., Taylor, E., et al., Proc. ODP, Sci. Results, 104: College Station, TX (Ocean Drilling Program), 611-662.
Martini, E., 1971. Standard Tertiary and Quaternary calcareous nannoplankton zonation. In Farinacci, A. (Ed.), Proc. 2nd Int. Conf. Planktonic Microfossils Roma: Rome (Ed. Tecnosci.), 2:739-785.

Okada, H., and Bukry, D., 1980. Supplementary modification and introduction of code numbers to the low-latitude coccolith biostratigraphic zonation (Bukry, 1973; 1975). Mar. Micropaleontol., 5:321-325.

Powell, A.J., 1992. Dinoflagellate cysts of the Tertiary System. In Powell, A.J. (Ed.), A Stratigraphic Index of Dinoflagellate Cysts: London (Chapman and Hall), 155-251.

Schroder, T., 1992. A palynological Zonation for the Paleocene of the North Sea basin. Journal of Micropalaeontology, 11:113-126.

Soper, N.J., and Costa, L.I., 1976. Palynological evidence for the age of Tertiary Basalts and post-basaltic sediments at Kap Dalton, central east Greenland. Rapp. Groenl. Geol. Unders., 123-127.

Soper, N.J., Downie, C., Higgins, A.C., and Costa, L.I., 1976a. Biostratigraphic ages of Tertiary basalts on the east Greenland continental margin and their relationship to plate separation in the northeast Atlantic. Earth Planet. Sci. Lett., 32:149-157.

Soper, N.J., Higgins, A.G., Downie, C., Matthews, D.W., and Brown, P.E., 1976b. Late Cretaceous-early Tertiary stratigraphy of the Kangerdlugssuaq area, east Greenland, and the age of opening of the north-east Atlantic. J. Geol. Soc. London, 132:85-104.

Wing, S.L., and Greenwood, D.R., 1994. Fossils and fossil climate: the case for equable continental interiors in the Eocene. In Allen, J.R.L., Hoskins B.J., Sellwood, B.W., Spicer, R.A., and Valdes, P.J. (Eds.), Palaeoclimates and their Modelling: London (Chapman \& Hall), 35-44.

Wolfe, J.A., 1979. Temperature parameters of humid to mesic forests of eastern Asia and relation to forests of other regions of the northern hemisphere and Australasia. Geol. Surv. Prof. Pap. U.S., 1106:1-37.

, 1981. A chronologic framework for Cenozoic megafossil floras of northwestern North America and its relation to marine geochronology. Spec. Pap.-Geol. Soc. Am., 184:39-47.

, 1990. Palaeobotanical evidence for a marked temperature increase following the Cretaceous/Tertiary boundary. Nature, 343:153-156.

Date of initial receipt: 7 November 1995

Date of acceptance: 3 August 1996 Ms 152SR-249

\section{APPENDIX}

Listing of pollen and spore taxonomic citations referred to in the text.

Alnipollenites verus (Potonie) Thomson and Pflug, 1953.

Caryapollenites circulus (Pflug) Krutzsch 1961.

C. veripites (Wilson and Webster) Nichols and Ott 1978.

Dicolpopollis luteticus (Gruas-Cavagnetto) Gruas-Cavagnetto 1975.

Inaperturopollenites distichiforme (Simpson) Jolley and Morton 1992.

Inaperturopollenites hiatus (Potonie) Thomson and Pflug 1953.

Intratriporopollenites microreticulatus Mai 1961.

Laevigatosporites haardtii (Potonie and Venitz) Pflug and Thomson 1953.

Nyssapollenites kruschii subsp. analepticus (Potonie) Pflug and Thomson 1953.

"Retitricolpites" retiformis Pflug and Thomson 1953.

Tricolpites hians Stanley 1965.

Triporopollenites robustus (Thomson and Pflug 1953. 


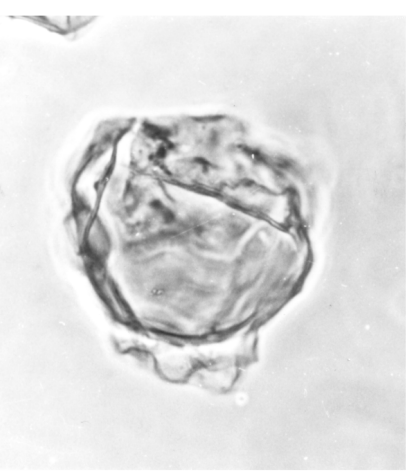

1

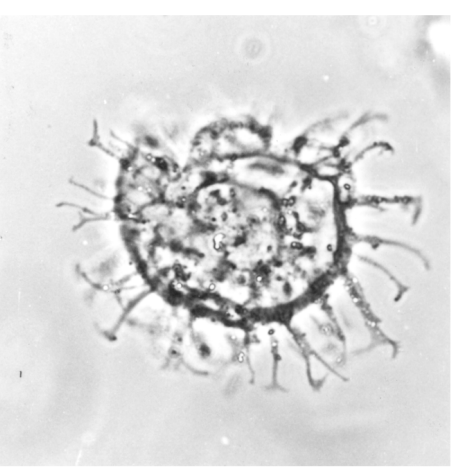

4

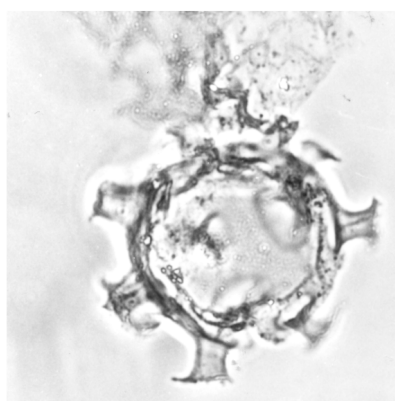

7

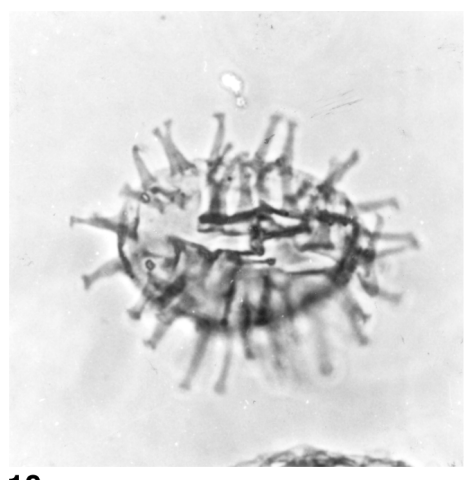

10

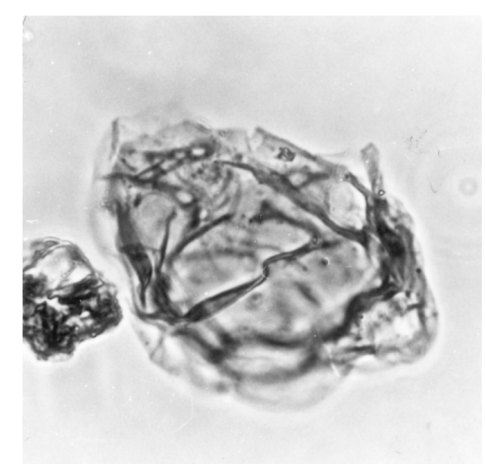

2

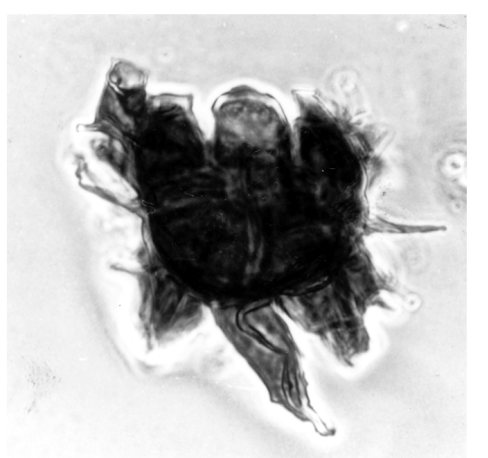

5
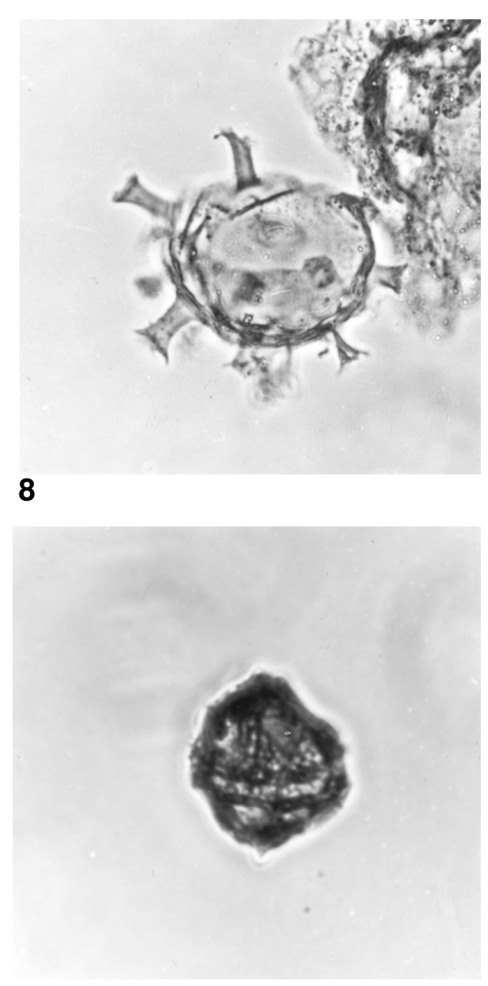

11

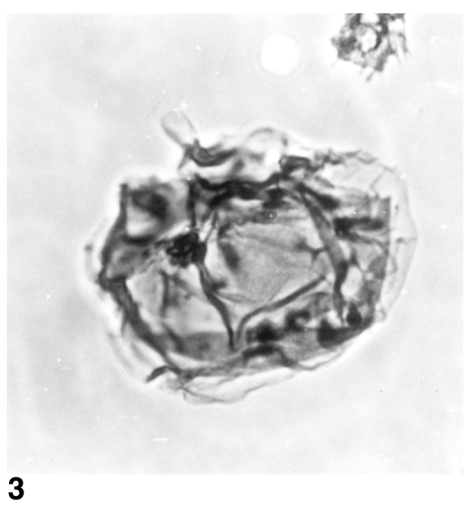

3

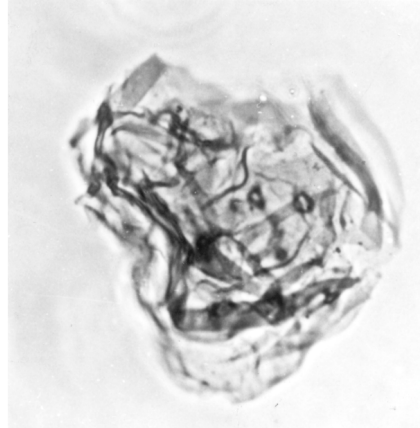

6
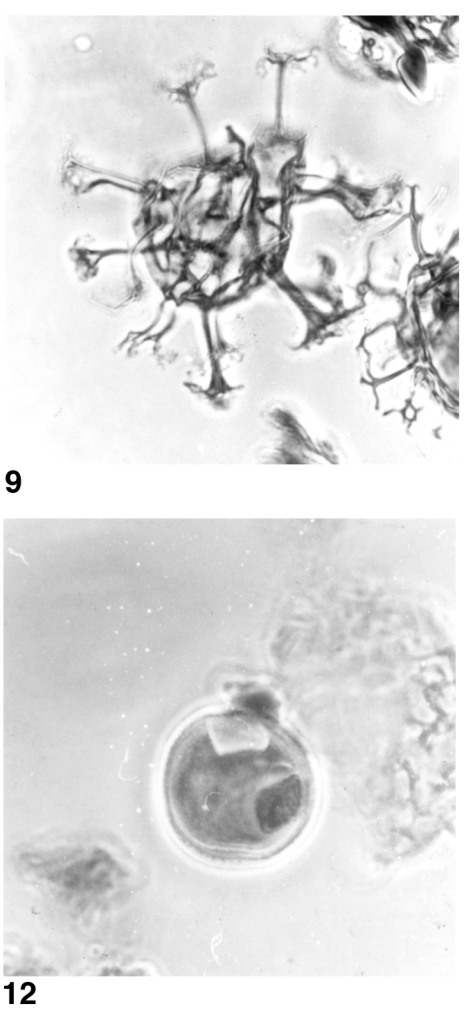

Plate 1. Photomicrographs of selected dinoflagellate cysts, pollen, and spores typical of the studied sections. All magnifications are at $750 \times$ for pollen and spores, and at 500× for microplankton. Captions include the depth and "England Finder" location of the specimens. 1. Mebranilarnacea sp. Hole 918D, 1186.45 m A, L33/3. 2. Mebranilarnacea sp. Hole 918D, $1186.45 \mathrm{~m}$ A, L37. 3. Mebranilarnacea sp. Hole 918D, $1186.45 \mathrm{~m}$ A, M30/2. 4. Systematophora ancyrea Hole 918D, 1157.54 m A, X38/4. 5. Hystrichokolpoma cinctum Hole 918D, 1156.44 m A, U35/3. 6. Mebranilarnacea sp. Hole 918D, 1186.45 m A, J37. 7. Homotryblium abbreviatum Hole 918D, 1157.54 m A, V44/2. 8. H. tenuispinosum Hole 918D, 1157.54 m A, H40/1. 9. Areosphaeridium diktyoplokus Hole 918D, 1156.44 m A, T41/3. 10. Polysphaeridium subtile Hole 918D, 1186.45 m A, M37/1. 11. Phthanoperidinium cf. flebile Hole 918D, 1181.63 m A, W30. 12. Tectatodinium cf. pellitum Hole 918D, $1156.44 \mathrm{~m}$ A, Q30. 


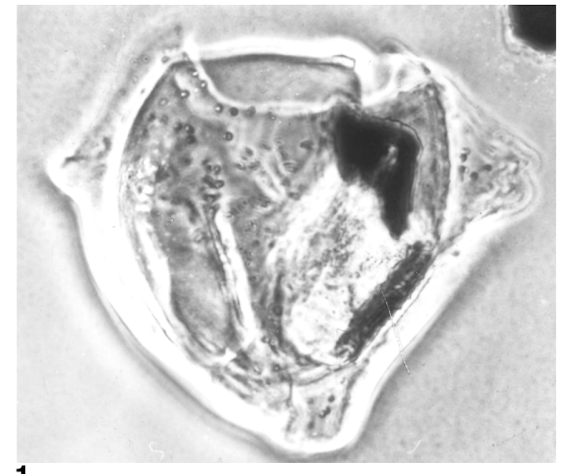

1

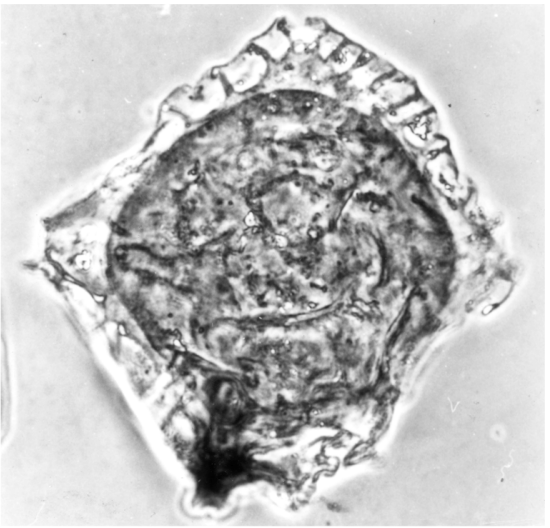

5

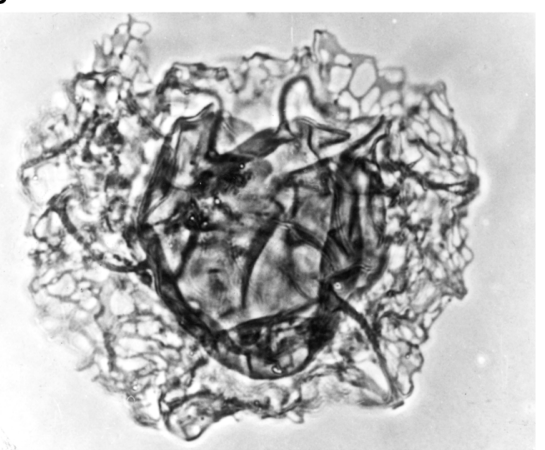

8

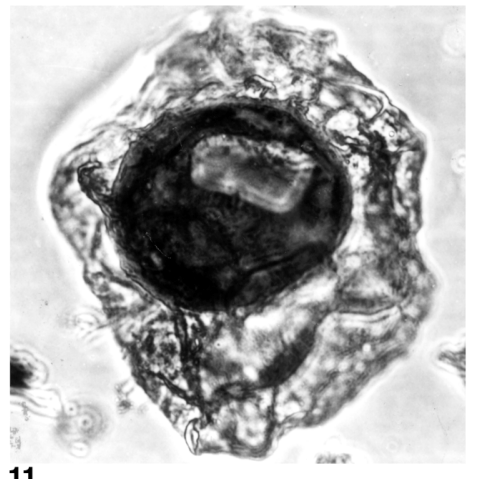

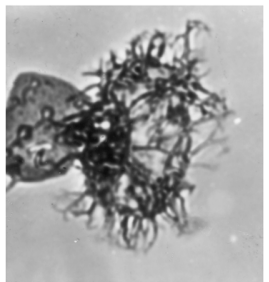

2

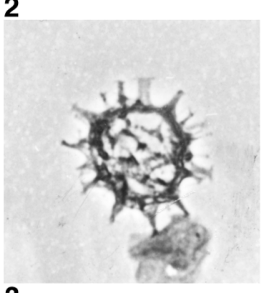

3

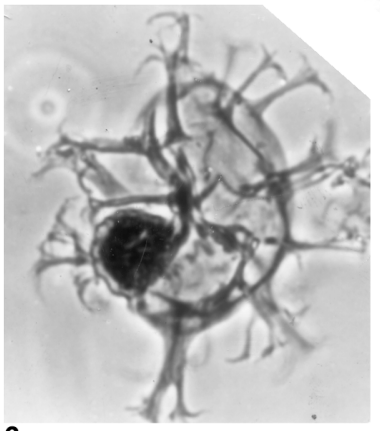

6

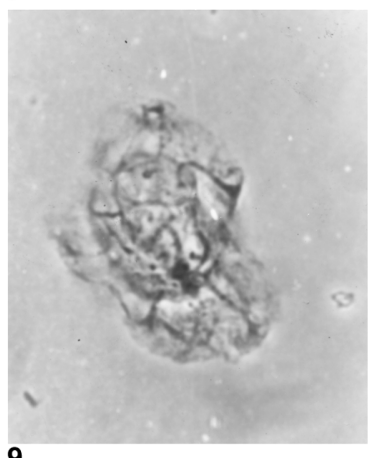

9

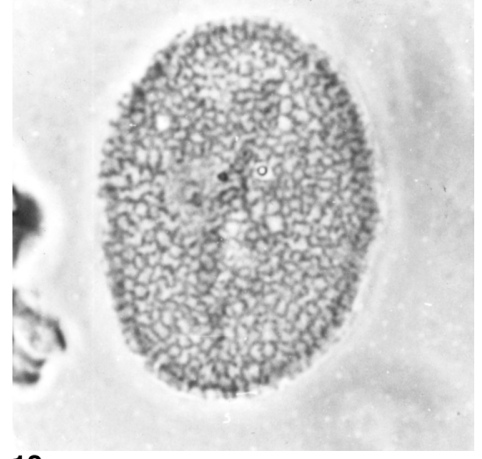

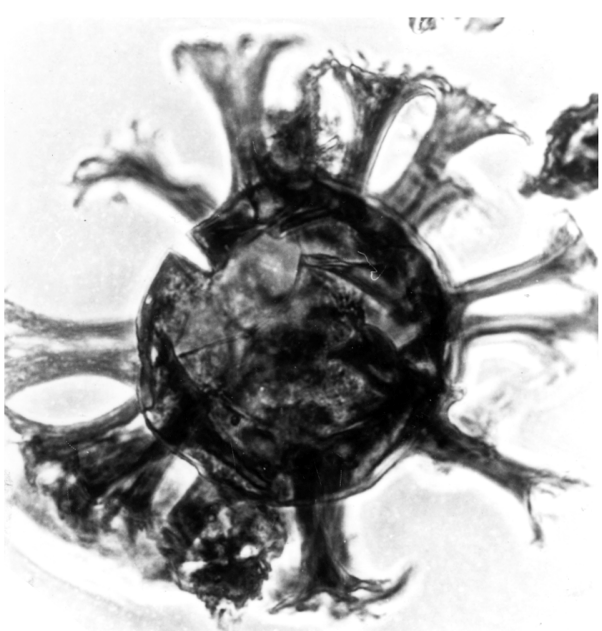

4

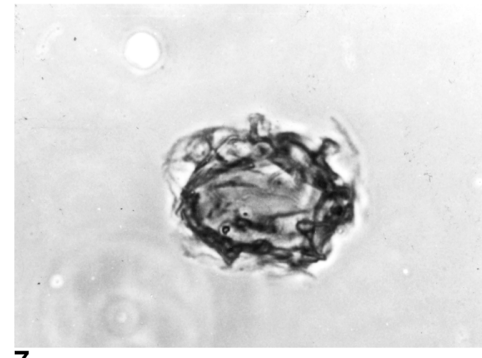

7

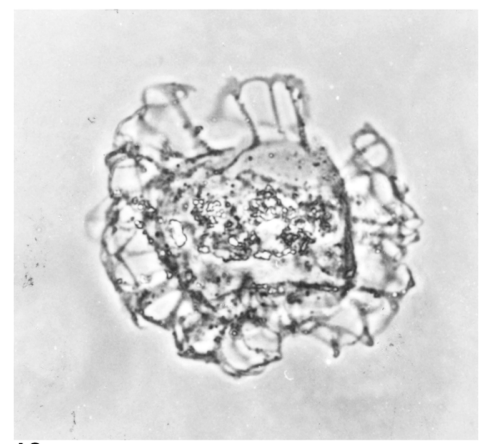

10

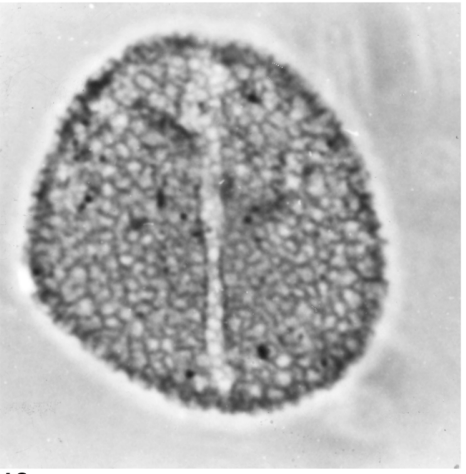

13

Plate 2. Photomicrographs of selected dinoflagellate cysts, pollen, and spores typical of the studied sections. All magnifications are at $750 \times$ for pollen and spores, and at 500× for microplankton unless otherwise stated. Captions include the depth and "England Finder" location of the specimens. 1. Dracodinium politum Hole 918D, $1187.71 \mathrm{~m} \mathrm{~A}, \mathrm{~K} 28 / 1$. 2. Impletosphaeridium implicatum Hole 918D, $1181.63 \mathrm{~m}$ A, U37. 3. Paucisphaeridium sp. A. Hole 918D, 1157.54 m A, T43/2. 4. Cordosphaeridium exilimurum Hole 918D, 1157.54 m A, V45. 5. Charlesdowniea coleothrypta Hole 918D, 1157.54 m A, U44/3. 6. Cordosphaeridium cracenospinosum Hole 918D, $1157.92 \mathrm{~m}$ A, V39/2. 7. Membranilarnacia compressa Hole 918D, $1156.44 \mathrm{~m}$ A, V32/2. 8. Eatonicysta ursulae Hole 918D, $1156.44 \mathrm{~m}$ A, O31. 9. Membranilarnacia glabra Hole 918D, $1166.36 \mathrm{~m} \mathrm{~A}$, W40. 10. Adnatosphaeridium multispinosum Hole 918D, 1157.54 m A, W44/3. 11. Thalassiphora pelagica 250×, Hole 918D, $1157.54 \mathrm{~m} \mathrm{~A}, \mathrm{H} 35 / 4$. 12. Arecipites brandenburgensis Hole 918D, $1157.54 \mathrm{~m}$ A, R47. 13. Arecipites brandenburgensis Hole 918D, 1185.81 m A, N42/3. 


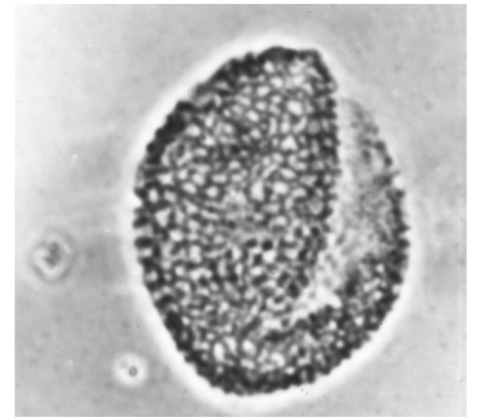

1

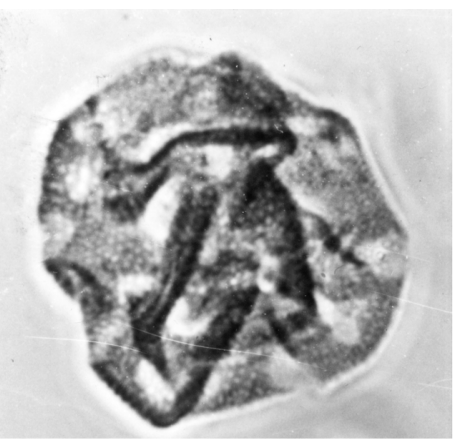

4

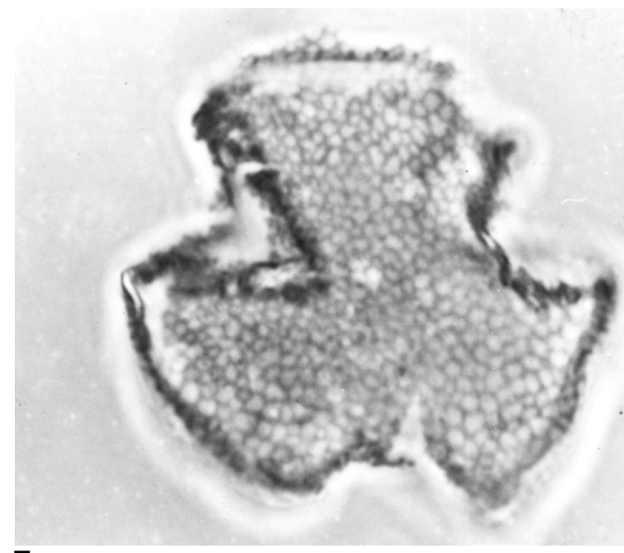

7

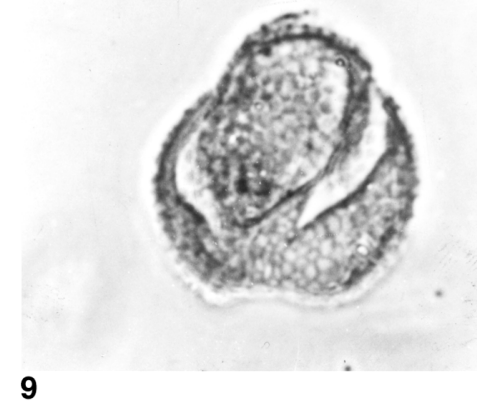

9

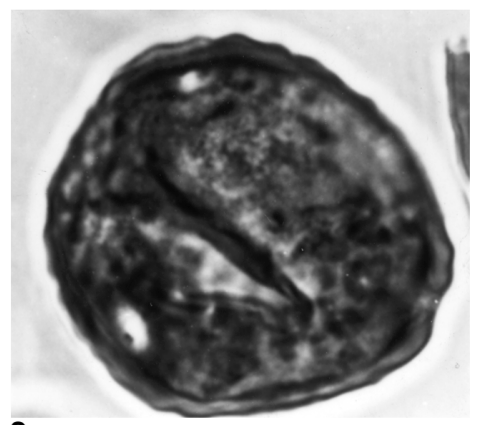

2

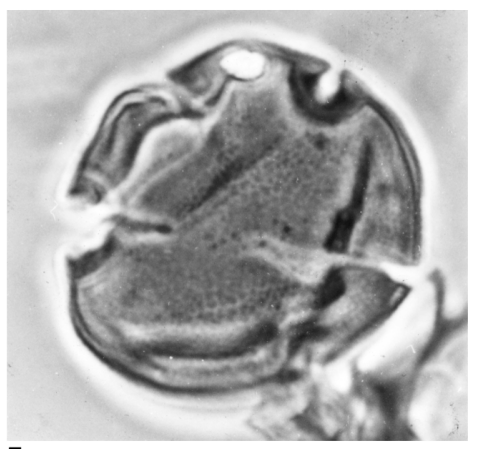

5

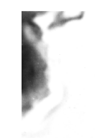

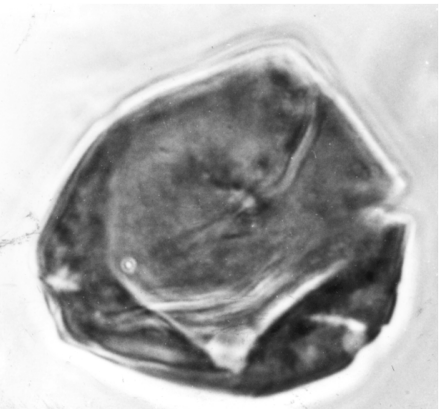

3

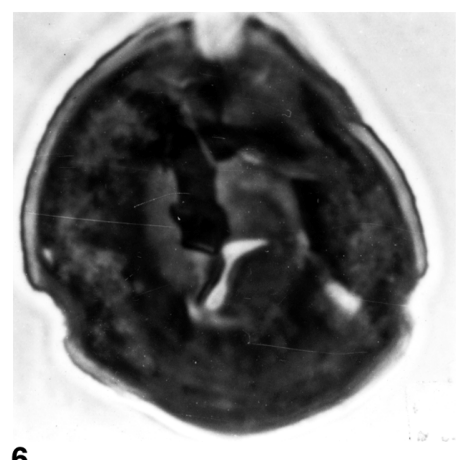

6

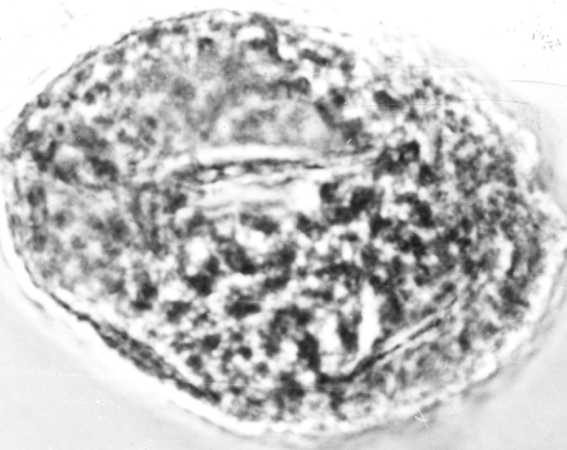

8

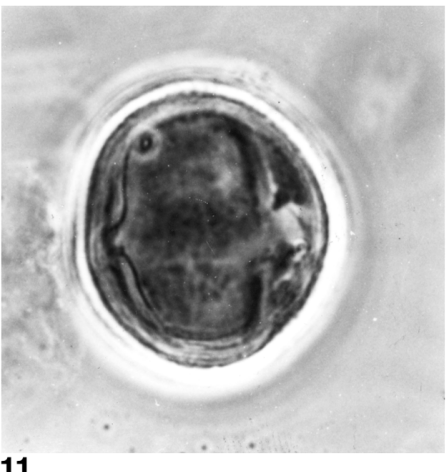

11

Plate 3. Photomicrographs of selected dinoflagellate cysts, pollen, and spores typical of the studied sections. All magnifications are at $750 \times$ for pollen and spores, and at $500 \times$ for microplankton. Captions include the depth and "England Finder" location of the specimens. 1. Arecipites brandenburgensis Hole 918D, $1166.36 \mathrm{~m}$ A, W40. 2. Ulmipollenites undulosus Hole 918D, 1185.81 m A, U43/3. 3. Caryapollenites veripites Hole 918D, 1185.37 m A, R36/2. 4. Liquidambarpollenites stigmosus Hole 916A, 88.85 m A, P30. 5. Intratiporopollenites microreticulatus Hole 918D, $1186.77 \mathrm{~m} \mathrm{A,} \mathrm{R34.} \mathrm{6.} \mathrm{Caryapollenites} \mathrm{circulus} \mathrm{Hole}$ 916A, 88.85 m A, L33/2. 7. Salixipollenites discolorpites Hole 918D, 1187.71 m A, K28/1. 8. Sciadopityspollenites serratus Hole 918D, 1185.7 m A, N45. 9. Retitricolpites anguloluminosus Hole 918D, $1185.81 \mathrm{~m} \mathrm{A,} \mathrm{M30.} \mathrm{10.} \mathrm{Ilexpollenites} \mathrm{iliacus} \mathrm{Hole} \mathrm{918D,} \mathrm{1185.81} \mathrm{m} \mathrm{A,} \mathrm{M28.} \mathrm{11.} \mathrm{Sapotaceoidaepollenites} \mathrm{kirchhe-}$ imerii Hole 918D, 1186.77 m A, L27/3. 